\title{
Application of Factor Analysis Method on Teaching Quality Satisfaction
}

\author{
Jixia Cao, a, Yuanda $\mathrm{Hou}^{2, \mathrm{~b}}$ and Qinzhen $\mathrm{Li}^{1, \mathrm{c}}$ \\ ${ }^{1}$ Military Transportation Commanding Department, Military Transportation University, Tianjin \\ 300161, China; \\ 2Science\&Research Office, Military Transportation University, Tianjin 300161, China. \\ acaojixia@sina.com, b523631052@qq.com, cvictory7501@126.com
}

\begin{abstract}
A survey on teaching quality satisfaction in 3 types of universities was carried out in this paper. Using Factor Analysis Method, raw data were calculated and analysis. Study conclusions were made: firstly, university teaching quality evaluation index system can be divided into a certain dimension; secondly, university students have different teaching quality satisfaction in different dimensions; thirdly, population variables can influence the university students' teaching quality satisfaction.
\end{abstract}

Keywords: university, teaching quality, satisfaction, factor analysis method.

\section{Introduction}

In this study, three four-year undergraduate universities in Tianjin was taken as examples, researching students' satisfaction with teaching quality for data analysis.

In this study, advanced educational thoughts and Factor Analysis Method (FAM) were applied for the study of higher education activities, thus to promote the theoretical system of higher education systems. In practice, this study of university students' satisfaction with the quality of teaching can contribute to improve the university's administration level and improve the quality of teaching, so as to optimize the configuration of variety of teaching resources in university, improve teaching methods and the effectiveness of teaching methods, then promote the further deepening of reform in higher education.

\section{Research Method and Tools}

\subsection{Research Background}

Reviewing the early experts and scholars' research results in Maslow's hierarchy of needs theory[1][2], Babanski's teaching process optimization theory[3][4] and total quality management[5], especially in higher education quality area, emphasis on customer satisfaction[6], student satisfaction[7], teaching quality satisfaction[8], application of factor analysis method[9]. The lack of research on university students' teaching quality satisfaction applied with factor analysis method was found.

\subsection{Questionnaire Design}

Research tools is "Teaching quality Satisfaction of University questionnaire", which is divided into two parts. The first part is students' personal information; The second part is the Teaching Quality satisfaction investigation form. Each one of the questions, with 5 points, the options are "strongly disagree" , "disagree", "no comments", "agree" and "strongly agree ", are assigned to 5,4,3,2,1 points, the higher of the score indicates the higher of satisfaction. 


\section{Survey and Analysis}

\subsection{Study Subjects}

The survey was carried out during date $10^{\text {th }}$ to $15^{\text {th }}$ January, 2018. The information of the survey was listed blow.

Table 1. Sample information of the questionnaire

\begin{tabular}{lcc}
\hline 1 & The total number & 252 \\
2 & Number received & 248 \\
3 & The number of valid sample & 246 \\
4 & Percentage of valid Survey & $99.19 \%$ \\
\hline
\end{tabular}

\subsection{Result Analysis}

Valid data of 246 groups were entered into SPSS 17.0 statistical software, forming 246 groups of raw data, each group includes personal information and student's satisfaction of 42 items.

\subsubsection{Factor Analysis}

Extract factor: by analyzing the principal component and extracting the factor, the eigenvalue greater than 1 in the 42 variables was found and form a common factor (results in Table 2). The contribution rate of common factor cumulative variance is $63.175 \%$, basically reflecting the most of the information in the original variables.

Table 2. Results of extracting factor

\begin{tabular}{cccc}
\hline Common factor & eigenvalue & $\begin{array}{c}\text { variance contribution } \\
\text { ratio }\end{array}$ & $\begin{array}{c}\text { accumulated variance } \\
\text { contribution ratio }\end{array}$ \\
\hline Factor 1 & 8.245 & 19.631 & 19.631 \\
Factor 2 & 3.528 & 8.401 & 28.032 \\
Factor 3 & 2.653 & 6.316 & 34.348 \\
Factor 4 & 2.497 & 5.944 & 40.292 \\
Factor 5 & 2.456 & 5.848 & 46.140 \\
Factor 6 & 2.377 & 5.660 & 51.800 \\
Factor 7 & 1.678 & 3.996 & 55.796 \\
Factor 8 & 1.559 & 3.712 & 59.509 \\
Factor 9 & 1.540 & 3.666 & 63.175 \\
\hline
\end{tabular}

From the factor stone graph, we can see the changes of top nine eigenvalue factors are very obvious, but changes from the ninth factor tended to be smooth, shown in fig. 1.

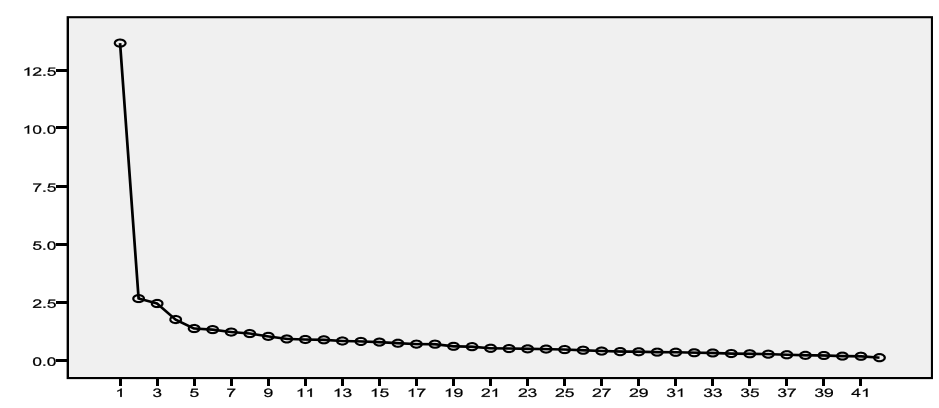

Fig. 1 Scree plot 
For ease of analysis, these nine factors were collected and analyzed, formatting three dimensions of evaluation index system for university teaching quality. Every factor was named and divided into three groups, shown in Table 3.

Table 3. Evaluation index system of the university teaching quality

\begin{tabular}{|c|c|}
\hline $\begin{array}{l}\text { Dimensionality } \\
\text { (primary index) }\end{array}$ & Main variable (second index) \\
\hline $\begin{array}{l}\text { Teachers and base } \\
\text { installation }\end{array}$ & $\begin{array}{l}\text { variable } 1 \text {, teachers qualification } \\
\text { variable } 2 \text {, teaching infrastructure }\end{array}$ \\
\hline Content and class hour assignment & $\begin{array}{c}\text { variable } 3 \text {,social practice } \\
\text { variable } 4 \text {,content of courses } \\
\text { variable9,curriculum arrangement }\end{array}$ \\
\hline $\begin{array}{l}\text { Learning situation of } \\
\text { students }\end{array}$ & $\begin{array}{l}\text { variable } 5 \text {,learning method of student } \\
\text { variable } 6 \text {,foundation of student } \\
\text { variable } 7 \text {, motivation of attending school } \\
\text { variable } 8 \text {, learning effect }\end{array}$ \\
\hline
\end{tabular}

From the table 3 , it is shown that there are three dimensions in the evaluation index system for university teaching quality, which is primary index. Each dimensionality has 2-4 evaluation variables, which is the second index. Teaching quality satisfaction in university has three primary index (dimensions) and nine secondary indexes (evaluation variables). The evaluation index system was built up.

\subsubsection{Description Statistics Analysis}

Means and standard deviations of these three groups of variables were calculated. Scores can be seen in the following Table 4.

Table 4. Mean and standard deviation of three dimensions

\begin{tabular}{cccc}
\hline Dimensions & $\begin{array}{c}\text { Teachers and } \\
\text { infrastructures }\end{array}$ & Teaching content and arrangement & Students learning \\
\hline Mean(M) & 3.39 & 3.18 & 3.58 \\
\hline Standard Deviation(SD) & 0.16 & 0.25 & 0.56 \\
\hline
\end{tabular}

It's can be shown mean and standard deviation of teaching quality satisfaction in three dimensions were $3.35 \pm 0.16,3.18 \pm 0.25,3.58 \pm 0.56$. According to this study, Likert scale used, medium number was 3, and the overall satisfaction was 3.46. The result shows that the average satisfaction of university students on teaching quality is "basically satisfied."

As the average score in Likert scale is 3 , take $10 \%$ of the average value as the separatrix to determine the difference obvious or not in this paper.

\subsubsection{Statistical Analysis}

Gender as an independent variable, 9 variables from evaluation index of teaching quality as dependent variables, independent sample $t$ test was implemented. Results of evaluation of the test between nine variables to gender variables $T$ test $P>0.05$. It showed that the gender factor of university students' teaching quality satisfaction in three dimensions has no significant difference, consistent with previous descriptive statistics.

Grade, universities' type, major as variable's independent samples t-test are as so on. 


\section{Study Conclusion}

\subsection{Evaluation Index System of University Teaching Quality Can be Divided into Three Dimensions, Nine Variables.}

Three dimensions are teachers and base installation, Content and class hour assignment, learning situation of students.

Nine variables are teacher's qualification, teaching infrastructure, social practice, content of courses, curriculum arrangement, motivation of attending school, learning method of student, foundation of student, student's learning effect.

\subsection{University Students have Different Teaching Quality Satisfaction in Different Dimensions.}

The highest satisfaction is learning situation of students, and the lowest one is Teachers and base installation. The results show that university students' average satisfaction scores are teachers, infrastructure and teachers \& base installation, whose scores are 3.35, 3.18 and 3.58, which proved that teaching quality satisfaction in each dimension is different.

Population variables can influence teaching quality satisfaction.

\section{References}

[1]. FA Freitas, LJ Leonard. Maslow's hierarchy of needs and student academic success. Teaching \& Learning in Nursing. Vol.6 (2011) No.6,p. 9-13.

[2]. MH Fisher, D Royster. Mathematics teachers' support and retention: using Maslow"s hierarchy to understand teachers' needs. International Journal of Mathematical Education in science \& technology. Vol.47 (2016) No.7,p.993-1008.

[3]. $X$ Guan, $X$ Huang, $H$ Wang. How to build up the teaching mode of develop thinking. International Conference on E-business \& E-government. Xi an, China, 10-12-2011, p.1-3.

[4]. J Xu, P Hui. Research and Practice on Network Instructional Design of Blended Learning Promoting the Optimization of Teaching Process. Second International Conference on Education Technology \& training. Huangshan, 5-10-2011, p.238-243.

[5]. H Osada. Strategic management by policy in total quality management. Strategic Change. Vol .7(2015) No.5, p.277-287.

[6]. Chong B, Wong M. Crafting an effective customer retention strategy: A review of halo effect on customer satisfaction in online auctions. International Journal of Management \& Enterprise Development. Vol.2(2017), No.1,p.36-40.

[7]. JH Wu, RD Tennyson, TL Hsia, A study of student satisfaction in a blended e-learning system environment. Computers \& Education. Vol.55(2010), No.1, p.155-164.

[8]. M Guolla. Assessing the Teaching Quality to Student Satisfaction Relationship:Applied Customer Satisfaction Research in the Classroom. Journal of Marketing Theory Practice. Vol.7(1999), No.3, p.87-97.

[9]. B Williams, L Mckenna, J French, S Dousek.The clinical teaching preference questionnaire (CTPQ): an exploratory factor analysis. Nurse Education Today. Vol.33(2013), No.8, p.814. 